\title{
A multi-proxy geochemical investigation of the early Paleocene (Danian) continental palaeoclimate at the Fontllonga-3 site (South Central Pyrenees, Spain)
}

\author{
Laura Domingo ${ }^{\text {a,* }}$, Nieves López-Martínez ${ }^{\mathrm{a}}$, \\ Rodrigo Soler-Gijón ${ }^{\mathrm{a}, \mathrm{b}}$, Stephen T. Grimes ${ }^{\mathrm{c}}$ \\ a Dept. Paleontología, Facultad CC, Geológicas. Universidad Complutense, 28040 Madrid, Spain \\ ${ }^{\mathrm{b}}$ Institut für Paläontologie, Museum für Naturkunde Humboldt Universität, D-10115 Berlin, Germany \\ ${ }^{\mathrm{c}}$ School of Earth, Ocean and Environmental Sciences, University of Plymouth, Drake Circus, PL4 8AA Plymouth, Devon, United Kingdom
}

Received 11 January 2007; received in revised form 6 August 2007; accepted 3 September 2007

\begin{abstract}
Chronologically well constrained non-marine deposits across the Cretaceous-Tertiary boundary (KTb) are exceptionally rare. The Fontllonga section (Tremp Formation, South Central Pyrenees, Lleida, Spain) constitutes one of these rare global records. Stable isotope $\left(\delta^{18} \mathrm{O}_{\mathrm{CO} 3}\right.$ and $\left.\delta^{13} \mathrm{C}\right)$ analyses have been performed on the carbonate fraction of 29 samples from diverse skeletal micro-remains (charophyte gyrogonites, gastropod shells, ostracod valves and isolated skeletal remains of lepisosteids and pycnodonts) from the earliest Danian site, Fontllonga-3. A mean $\mathrm{Ba} / \mathrm{Ca}$ water palaeotemperature of $28.0 \pm 6.7^{\circ} \mathrm{C}$ has been obtained from the ganoine of 25 lepisosteid scales. This mean palaeotemperature is comparable with the temperature tolerance range for extant relatives of fossil osteoglossiform fish found at Fontllonga-3, which require a temperature range of $24^{\circ}-35^{\circ} \mathrm{C}$ (mean annual temperature $\left.27-30^{\circ} \mathrm{C}\right)$ to survive. Using the temperature range provided by the $\mathrm{Ba} / \mathrm{Ca}$ palaeothermometer $\left(21.3-34.7^{\circ} \mathrm{C}\right)$, it is possible to determine $\delta^{18} \mathrm{O}_{\text {water }}$ values from the isotopic content of charophyte gyrogonites, gastropod shells, ostracod valves and fish remains (mean $\delta^{18} \mathrm{O}_{\mathrm{CO} 3}=-5.00 \%, \sigma=0.21$ ). $\delta^{18} \mathrm{O}_{\text {water }}$ values of between -4.01 and $-0.95 \%$ (VSMOW) are calculated, which, when combined with $(\mathrm{La} / \mathrm{Yb})_{\mathrm{N}}$ versus $(\mathrm{La} / \mathrm{Sm})_{\mathrm{N}}$ plots, are in good agreement with the sedimentary interpretation of the site as an estuarine environment. Based upon a comparison with modern day meteorical conditions these isotopic values are relatively high for subtropical freshwaters, suggesting a low precipitation rate (amount effect, high evaporation rate and/or long residence time). When combined with other isotopic, palaeobotanical and mineralogical studies carried out in the Pyrenean and Tethys realms this first geochemical study of an early Paleocene site is consistent with there being a subtropical seasonally dry climate in the South Central Pyrenees at this time.
\end{abstract}

Keywords: Oxygen and carbon isotopes; Apatite; Barium/calcium palaeothermometer; Fontllonga-3; Estuarine

* Corresponding author. Tel.: +34 913944875; fax: +34 913944849.

E-mail address: lauradomingo@geo.ucm.es (L. Domingo).

\section{Introduction}

Understanding past climatic conditions has become of paramount importance to unveiling the mechanisms that control the Earth's climate. During the last few 
decades stable isotope studies involving marine invertebrate fossils have allowed the estimation of the palaeoclimatic and palaeoenvironmental variations for the last $100 \mathrm{Ma}$ (i.e. Shackleton and Opdike, 1973; Shackleton, 1986, Kennett and Stott, 1990; Huber et al., 1995; Norris and Wilson, 1998; Zachos et al., 2001). Continental fossils have not received the same attention, owing to perceived pitfalls such as diagenetic alteration, pedogenic processes, lack of continuity in the continental sedimentary record, etc. Nevertheless, if treated correctly continental fossils can provide valuable information which is absent in the marine record, such as air temperature, humidity and precipitation sources. For this reason, isotopic studies on continental fossils are currently being vigorously pursued (e.g., Koch et al., 1995; Fricke et al., 1998; Grimes et al., 2003, 2005; Tütken et al., 2006).

A wide range of continental fossils have extensively been used with this aim. For example, Koch et al. (1995) and Fricke et al. (1998) measured the oxygen isotope composition of mammalian tooth enamel, fish ganoine and bivalves shells to determine the mean palaeoclimatic conditions that occurred during the Paleocene-Eocene transition. Other authors have obtained seasonal temperature patterns by studying bone and enamel from different kinds of vertebrates such as mammals, fishes, dinosaurs etc. (e.g., Higgins and MacFadden, 2004; MacFadden et al., 2004; Tütken et al., 2004; Straight et al., 2004). Kohn and Law (2006) have argued that during fossilization bone is prone to recrystallization and alters chemically on timescales of a thousand to a few tens of thousand of years and therefore the isotopic composition of fossil bones can be interpreted in the same way as those provided by palaeosoils.

The Cretaceous-Tertiary transition has been extensively documented in the marine realm (Smit, 1990; Kaiho et al., 1999), but events in continental environments, such as the extinction of dinosaurs, extraterrestrial impact signals and isotopic anomalies at the CretaceousTertiary boundary $(\mathrm{KTb})$ have only been studied in a few North American (Lerbekmo and St Louis, 1986), French (Jaeger and Westphal, 1989) and Chinese sections (Zhao et al., 1991). Therefore, the study of new continental sections across the $\mathrm{KTb}$ is important in order to derive an integrated vision of the mechanisms behind one of the major biological crisis known in the history of Earth.

The South Central Pyrenees is one of the best locations in Europe to characterize the KTb transition using different reconstruction techniques (i.e., palaeontology, magnetostratigraphy, chemostratigraphy, etc.). Previous studies have constrained the chronology of the Fontllonga section (Tremp Formation, Lleida, Spain) enabling the KTb to be located within a 3 m interval (López-Martínez et al., 1996, 1998) of the coastal red-bed deposits. Just above this interval, the earliest Danian Fontllonga-3 site has yielded a rich fossil content of well-preserved vertebrate and invertebrate remains (Soler-Gijón and de la Peña, 1995; LópezMartínez et al., 1998; Peláez-Campomanes et al., 2000). In this study we have performed geochemical analyses on a range of fossils from this exceptional site, in order to infer the palaeoclimatic and palaeoenvironmental conditions in the continental realm during this critical period just after the $\mathrm{KTb}$ in the South Central Pyrenees (Lleida, Spain).

\section{Geological setting}

The Pyrenean basin was formed subsequent to the opening of the Bay of Biscay during the Lower Cretaceous. The Fontllonga- 3 site belongs to the Tremp Formation which constitutes the last infilling episode of the Cretaceous basin. The transitional and non-marine deposits of the Tremp Formation (Upper CampanianLower Eocene) are underlain and intercalated at their base with the marine Aren Sandstone (Upper CampanianLower Maastrichtian) and overlain by the Ilerdian transgressive Alveolina limestones and marls (Lower Eocene) (Mey et al., 1968; Nagtegaal et al., 1983). In the earliest Danian, the South Central Pyrenees were situated at a palaeolatitude of $35^{\circ} \mathrm{N}$ (Schmitz and Pujalte, 2003; Fernández-Marrón et al., 2004; Fig. 1).

The age of the Tremp Formation is underpinned by biostratigraphy, palaeomagnetism and stable isotope studies (Feist and Colombo, 1983; Galbrun et al., 1993; López-Martínez et al., 1998, 1999; Mayr et al., 1999; Fernández-Marrón et al., 2004). The Fontllonga-3 site is located near the top of Unit 2 of the Tremp Formation (Galbrun et al., 1993; Fig. 2). It is a lenticular clay bed interpreted as an ox-bow lake fill, intercalated in the uppermost part of a thickening upward sequence of channelled sandstone bodies, up to $15 \mathrm{~m}$ thick, which shows lateral accretion (point bar structure) and sigmoidal stratification, indicating tidal influences. This sandstone unit can be correlated across the $30 \mathrm{~km}$ wide Ager syncline and has been interpreted as an upper estuary deposit (Álvarez-Sierra et al., 1994; López-Martínez et al., 1998).

The last localities with dinosaur footprints (Mas Morull and Sta. Maria de Meià) are situated approximately $3 \mathrm{~m}$ below Fontllonga-3, a time span of 75-100 ky (Fernández-Marrón et al., 2004). The KTb occurs within a 1$3 \mathrm{~m}$ thick lutite interval near the top of the sandstone unit, although no iridium peak has been found yet. Just above the KTb interval, López-Martínez et al. (1998) reported a negative $\delta{ }^{13} \mathrm{C}$ excursion (Fig. 2). This negative 


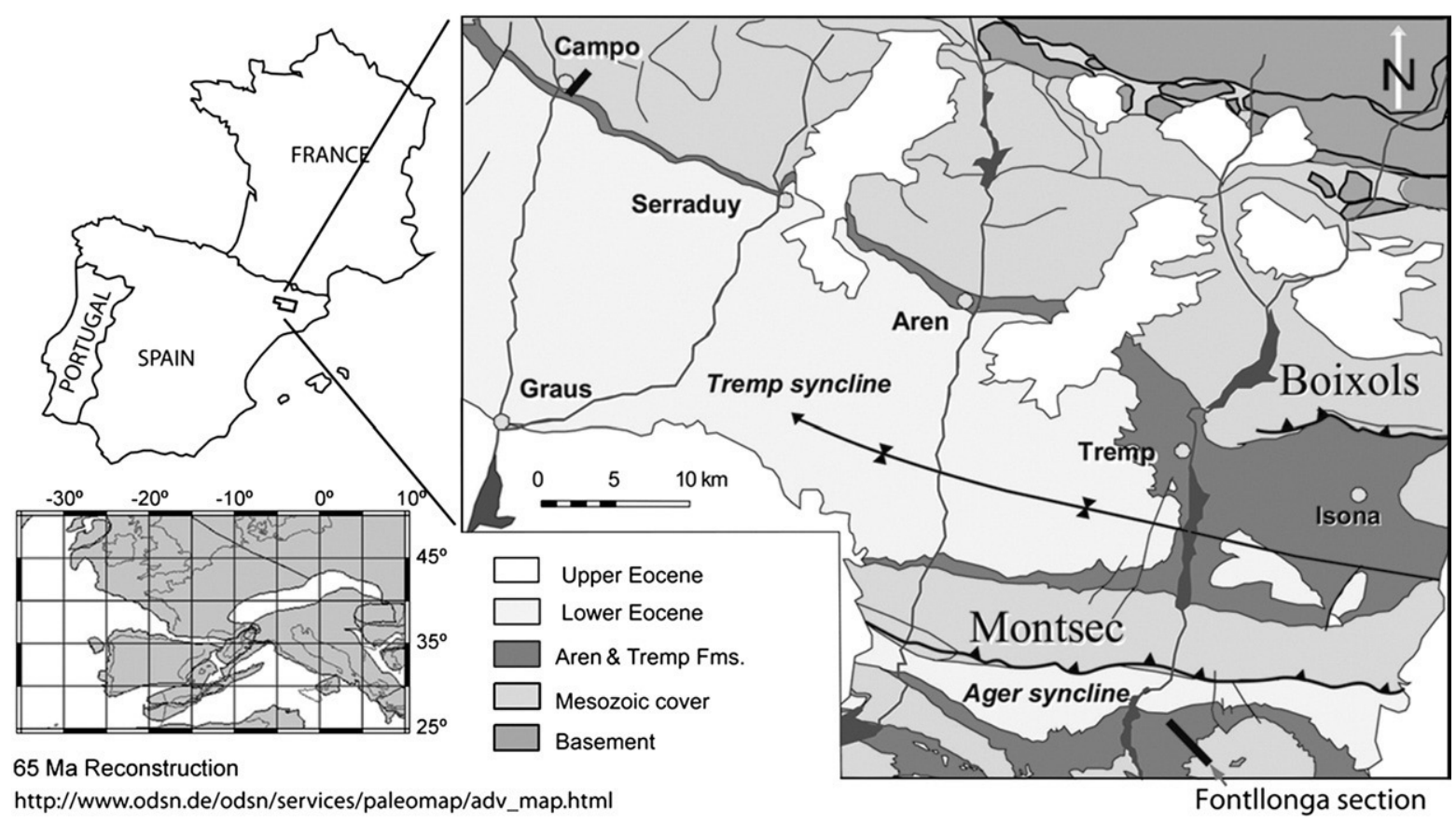

Fig. 1. Geological map of the studied area showing the Fontllonga section and a palaeogeographic map for the uppermost Maastrichtian-lowermost Palaeocene interval (Fernández-Marrón et al., 2004). Plate reconstruction according to http://www.odsn.de/odsn/services/paleomap/adv_map.html.

excursion coincides in amplitude and direction with the widely described drop occurring just above the KTb in marine sections (Perch-Nielsen et al., 1982; "Strangelove ocean" of Hsü and McKenzie, 1985; "z event" of Shackleton, 1986; Margolis et al., 1987; Corfield, 1994). The Fontllonga-3 site has also been correlated to the upper part of chron C29r (earliest Danian; Galbrun et al., 1993).

An exhaustive sampling of Fontllonga-3 has yielded a large number of fish bones, teeth and scales (see SolerGijón and López-Martínez, 2005), bird eggshells and some mammal teeth (such as the multituberculate Hainina). The presence of Coelodus cf. laurenti, known in the Paleocene of the Paris Basin (Soler-Gijón and de la Peña, 1995) along with the Normapolles taxon Pseudoromeinipollenites paleocenicus (Kedves, 1982) indicates an Early Danian age for Fontllonga-3. Thus, this site represents the earliest Tertiary non-marine vertebrate fauna from the Old World (Peláez-Campomanes et al., 2000).

\section{Material and methods}

Eight different types of fossils from the Fontllonga-3 site have been analysed in this study: charophyte gyrogonites, gastropod shells, ostracod valves, lepisosteid scales, teeth and bones and pycnodont vomerine and branchial teeth. The scarcity of fossil mammal remains means that they have not been analysed, owing to the destructive procedure and the high value placed upon these fossils.

All the fossils were separated from the host sediment by first hand-picking under a binocular microscope and then by washing with distilled water in an ultrasonic bath. Charophyte gyrogonites, gastropod shells and ostracod valves were carefully checked to ensure that they did not contain any infilling or adhering sediment before being crushed in an agate mortar and pestle. Whole lepisosteid teeth and scales and pycnodont teeth were crushed and analysed, though for a number of lepisosteid scales the ganoine was separated from the isopedine, in order to distinguish the geochemical signals produced by these two hard tissues.

The Rare Earth Element (REE) content of a representative lepisosteid vertebra and the ganoine of 16 lepisosteid scales were determined. PAAS values (PostArchean Australian Shale of Taylor and McLennan, 1985) were used to normalize the raw REE data. The powdered vertebra sample was fused with ultrapure lithium metaborate flux, dissolved while molten in $\mathrm{HNO}_{3}$ and analyzed on a Varian, inductively coupled plasma source mass spectrometer (ICP-MS) at the C.A.I. Espectrometría Atómica of the Complutense University (Madrid, Spain). The powdered ganoine samples were digested with $4 \mathrm{M}$ 


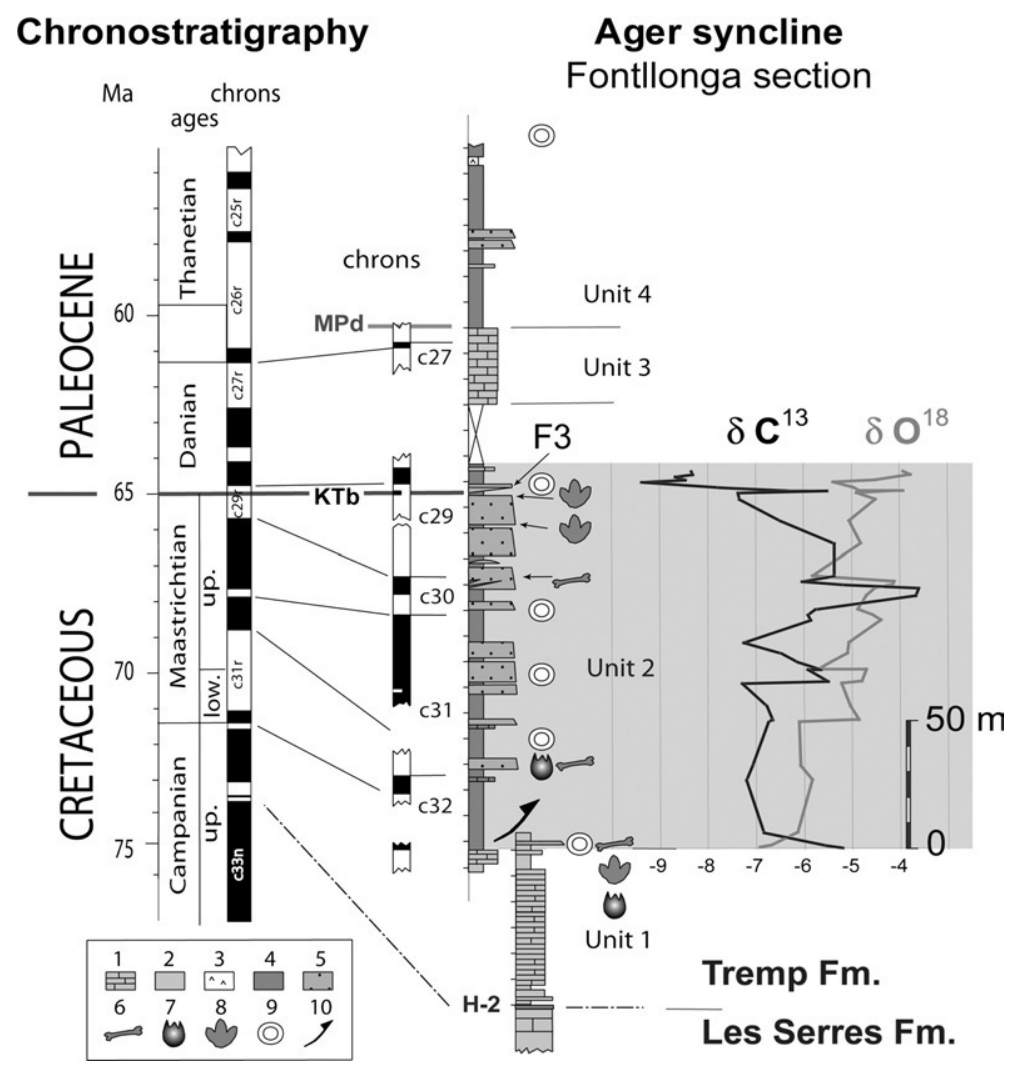

Fig. 2. Stratigraphy (López-Martínez et al., 1996) and palaeomagnetic data (Galbrun et al., 1993) of the Fontllonga section. The $\delta^{13} \mathrm{C}$ and $\delta^{18} \mathrm{O}$ curves were obtained from limestones, marls, palaeosols and oncoids (López-Martínez et al., 1998). It can be observed the major carbon anomaly detected in marine sections that corresponds to the "z event" (Shackleton,1986) or to the "Strangelove ocean" (Hsü and McKenzie, 1985) just above the KTb. F3 refers to Fontllonga-3. 1: limestones, 2: marls, 3: gypsum, 4: lutites, 5: sandstones, 6: dinosaur bones, 7: dinosaur eggs, 8: dinosaur footprints, 9: oncolites, 10: faults.

$\mathrm{HNO}_{3}$ and diluted in ultrapure water. These samples were analysed on a PlasmaQuad PQ2+, inductively coupled plasma source mass spectrometer (ICP-MS) at the University of Plymouth (Plymouth, United Kingdom). The accuracy for each REE analysed is better than $5 \%$ of its concentration.

The $\delta^{13} \mathrm{C}$ and $\delta^{18} \mathrm{O}_{\mathrm{CO} 3}$ isotopic ratios were measured on carbonate invertebrates as well as vertebrate fish remains composed of bioapatite. Although most studies dealing with vertebrates usually measure $\delta^{18} \mathrm{O}_{\mathrm{PO} 4}$ (e.g. Ayliffe et al., 1994; Bryant et al., 1996; Fricke et al., 1998; Pucéat et al., 2003; Billon-Bruyat et al., 2005; Grimes et al., 2005, etc.) as it is less prone to suffer from diagenetic alteration, some studies have demonstrated that the $\delta^{18} \mathrm{O}_{\mathrm{CO} 3}$ isotopic component of bioapatite can also record palaeoclimatic information (Wang and Cerling, 1994; Koch et al., 1995; Bocherens et al., 1996; Higgins and MacFadden, 2004; MacFadden et al., 2004; Tütken et al., 2004; Kohn and Law, 2006). The bioapatite samples were first treated with a weak $(0.1 \mathrm{~N})$ acetic acid solution to remove any exogenous carbonates. $\mathrm{CO}_{2}$ from all samples (bioapatites and carbonates) was obtained by acid hydrolysis using pure phosphoric acid $\left(\mathrm{H}_{3} \mathrm{PO}_{4}\right)$ with a reaction time of $24 \mathrm{~h}$ at $25{ }^{\circ} \mathrm{C}$. Isotopic ratios were determined in a SIRA II mass spectrometer. Samples were calibrated against both an inter-laboratory and an international standard (EEZ 1 and NBS 19). The carbon and oxygen isotopic results are reported in the standard $\delta$-notation against VPDB (Vienna-Pee Dee Belemnite). Reproducibility for $\delta^{13} \mathrm{C}$ and $\delta{ }^{18} \mathrm{O}$ measurements is $\pm 0.1 \%$ and $\pm 0.15 \%$, respectively. Samples were analyzed at the Servicio General de Análisis de Isótopos Estables of the Salamanca University (Salamanca, Spain).

$\mathrm{Ba} / \mathrm{Ca}$ palaeotemperatures were determined following the method of Balter and Lécuyer (2004), where the thermodependence of $\mathrm{Ba}$ partitioning between apatite and water at low temperature is such that:

$$
\begin{aligned}
& \log \left(K_{\text {apatite-water }}^{\mathrm{Ba} / \mathrm{Ca}}\right) \\
& \quad=1.96 \pm 0.06\left(10^{3} T^{-1}\right)-7.19 \pm 0.20\left(r^{2}=0.99\right)
\end{aligned}
$$

where $T$ is the temperature in degrees Kelvin. 
Ba concentrations were determined by using the same method as that described for the REE analyses on the ganoine. Ca concentrations were measured by using an AAS Varian Spectr AA at the University of Plymouth (Plymouth, United Kingdom). The international standard "1400 Bone Ash" was used in accordance with protocol outlined by Balter and Lécuyer (2004).

\section{Results}

\subsection{Rare Earth Elements (REE)}

The REE content of a lepisosteid vertebra and the ganoine of 16 lepisosteid scales from Fontllonga-3 have been determined (Table 1) and compared with vertebrate remains from neighbouring Late Cretaceous sites (Laño, Urria and Cuezva, northern Spain; Lécuyer et al., 2003b, Fig. 3). Laño samples display flat or "hatshaped" patterns, with $0.66-1.59(\mathrm{La} / \mathrm{Sm})_{\mathrm{N}}$ ratios and $1.03-3.12(\mathrm{Gd} / \mathrm{Yb})_{\mathrm{N}}$ ratios. Urria and Cuezva samples are characterized by "bell-shaped" patterns with low $(\mathrm{La} / \mathrm{Sm})_{\mathrm{N}}$ ratios $(0.03-0.24)$ and strong middle REE enrichments: $(\mathrm{Gd} / \mathrm{Yb})_{\mathrm{N}}$ ratios range between 4.51 and 7.59. Fontllonga-3 samples displays a flat REE pattern similar to Laño, with intermediate values (La/ $\mathrm{Sm})_{\mathrm{N}}=0.50$ and $(\mathrm{Gd} / \mathrm{Yb})_{\mathrm{N}}=4.14$ for the lepisosteid vertebra and $(\mathrm{La} / \mathrm{Sm})_{\mathrm{N}}=0.52$ and $(\mathrm{Gd} / \mathrm{Yb})_{\mathrm{N}}=3.25$ for the lepisosteid ganoine. According to Reynard et al. (1999), the "bell-shaped" REE patterns are due to extensive recrystallization of the apatite in the presence

Table 1

Rare Earth Element $(\mathrm{REE})$ content and $(\mathrm{La} / \mathrm{Sm})_{\mathrm{N}},(\mathrm{La} / \mathrm{Yb})_{\mathrm{N}},(\mathrm{Gd} / \mathrm{Yb})_{\mathrm{N}}$ ratios of lepisosteid vertebra and ganoine from Fontllonga-3 site

\begin{tabular}{|c|c|c|c|c|c|c|c|c|c|c|c|c|c|c|c|c|c|}
\hline Sample & $\begin{array}{l}\text { Skeletal } \\
\text { element }\end{array}$ & $\mathrm{La}$ & $\mathrm{Ce}$ & $\operatorname{Pr}$ & $\mathrm{Nd}$ & $\mathrm{Sm}$ & $\mathrm{Eu}$ & $\mathrm{Gd}$ & $\mathrm{Tb}$ & Dy & Ho & Er & $\mathrm{Yb}$ & $\mathrm{Lu}$ & $\begin{array}{l}(\mathrm{La} / \\
\mathrm{Sm})_{\mathrm{N}}\end{array}$ & $\begin{array}{l}(\mathrm{La} / \\
\mathrm{Yb})_{\mathrm{N}}\end{array}$ & $\begin{array}{l}(\mathrm{Gd} / \\
\mathrm{Yb})_{\mathrm{N}}\end{array}$ \\
\hline $\begin{array}{l}\text { FONT 3-05- } \\
\text { REE }\end{array}$ & Vertebra & 8.17 & 9.65 & 10.65 & 10.68 & 17.10 & 17.59 & 22.32 & 18.73 & 17.18 & 14.43 & 11.68 & 5.39 & 4.50 & 0.50 & 2.14 & 4.14 \\
\hline $\begin{array}{l}\text { FONT 3-07- } \\
\text { CG-2 }\end{array}$ & Ganoine & 0.20 & 0.21 & 0.24 & 0.24 & 0.38 & 0.44 & 0.56 & 0.66 & 0.46 & 0.56 & 0.35 & 0.17 & 0.45 & 0.53 & 1.21 & 3.40 \\
\hline $\begin{array}{l}\text { FONT 3-07- } \\
\text { CG-3 }\end{array}$ & Ganoine & 0.27 & 0.28 & 0.32 & 0.33 & 0.50 & 0.56 & 0.75 & 0.80 & 0.62 & 0.67 & 0.46 & 0.21 & 0.38 & 0.54 & 1.27 & 3.53 \\
\hline $\begin{array}{l}\text { FONT 3-07- } \\
\text { CG-4 }\end{array}$ & Ganoine & 0.25 & 0.27 & 0.31 & 0.32 & 0.47 & 0.52 & 0.70 & 0.74 & 0.59 & 0.63 & 0.44 & 0.20 & 0.36 & 0.53 & 1.25 & 3.47 \\
\hline $\begin{array}{l}\text { FONT 3-07- } \\
\text { CG-5 }\end{array}$ & Ganoine & 0.20 & 0.21 & 0.24 & 0.24 & 0.36 & 0.40 & 0.53 & 0.59 & 0.45 & 0.52 & 0.35 & 0.16 & 0.32 & 0.57 & 1.29 & 3.39 \\
\hline $\begin{array}{l}\text { FONT 3-07- } \\
\text { CG-6 }\end{array}$ & Ganoine & 0.26 & 0.26 & 0.29 & 0.29 & 0.43 & 0.47 & 0.67 & 0.71 & 0.56 & 0.63 & 0.43 & 0.20 & 0.37 & 0.59 & 1.29 & 3.39 \\
\hline $\begin{array}{l}\text { FONT 3-07- } \\
\text { CG-7 }\end{array}$ & Ganoine & 0.54 & 0.55 & 0.60 & 0.62 & 0.88 & 0.92 & 1.41 & 1.40 & 1.21 & 1.15 & 0.86 & 0.39 & 0.54 & 0.61 & 1.38 & 3.61 \\
\hline $\begin{array}{l}\text { FONT 3-07- } \\
\text { CG-8 }\end{array}$ & Ganoine & 0.46 & 0.50 & 0.57 & 0.60 & 0.89 & 0.99 & 1.24 & 1.26 & 1.05 & 0.99 & 0.74 & 0.34 & 0.49 & 0.51 & 1.34 & 3.65 \\
\hline $\begin{array}{l}\text { FONT 3-07- } \\
\text { CG-10 }\end{array}$ & Ganoine & 0.19 & 0.18 & 0.22 & 0.21 & 0.31 & 0.34 & 0.47 & 0.53 & 0.41 & 0.50 & 0.31 & 0.15 & 0.32 & 0.60 & 1.27 & 3.21 \\
\hline $\begin{array}{l}\text { FONT 3-07- } \\
\text { CG-11 }\end{array}$ & Ganoine & 0.23 & 0.23 & 0.27 & 0.26 & 0.42 & 0.41 & 0.59 & 0.65 & 0.51 & 0.57 & 0.38 & 0.19 & 0.35 & 0.54 & 1.20 & 3.16 \\
\hline $\begin{array}{l}\text { FONT 3-07- } \\
\text { CG-13 }\end{array}$ & Ganoine & 0.32 & 0.34 & 0.39 & 0.39 & 0.59 & 0.62 & 0.85 & 0.91 & 0.75 & 0.75 & 0.53 & 0.24 & 0.43 & 0.54 & 1.34 & 3.57 \\
\hline $\begin{array}{l}\text { FONT 3-07- } \\
\text { CG-15 }\end{array}$ & Ganoine & 0.21 & 0.23 & 0.28 & 0.29 & 0.47 & 0.47 & 0.63 & 0.69 & 0.52 & 0.58 & 0.39 & 0.17 & 0.34 & 0.45 & 1.20 & 3.61 \\
\hline $\begin{array}{c}\text { FONT 3-07- } \\
\text { CG-20 }\end{array}$ & Ganoine & 0.20 & 0.21 & 0.25 & 0.26 & 0.41 & 0.45 & 0.58 & 0.62 & 0.49 & 0.55 & 0.37 & 0.17 & 0.34 & 0.48 & 1.18 & 3.48 \\
\hline $\begin{array}{c}\text { FONT 3-07- } \\
\text { CG-21 }\end{array}$ & Ganoine & 0.42 & 0.41 & 0.45 & 0.46 & 0.61 & 0.73 & 1.06 & 1.10 & 0.91 & 0.89 & 0.64 & 0.31 & 0.48 & 0.69 & 1.37 & 3.46 \\
\hline $\begin{array}{l}\text { FONT 3-07- } \\
\text { CG-22 }\end{array}$ & Ganoine & 0.15 & 0.16 & 0.18 & 0.19 & 0.30 & 0.30 & 0.42 & 0.48 & 0.36 & 0.44 & 0.28 & 0.13 & 0.32 & 0.50 & 1.17 & 3.35 \\
\hline $\begin{array}{l}\text { FONT 3-07- } \\
\text { CG-23 }\end{array}$ & Ganoine & 0.14 & 0.15 & 0.19 & 0.19 & 0.31 & 0.34 & 0.42 & 0.47 & 0.35 & 0.46 & 0.29 & 0.14 & 0.32 & 0.45 & 1.00 & 3.05 \\
\hline $\begin{array}{l}\text { FONT 3-07- } \\
\text { CG-24 }\end{array}$ & Ganoine & 0.11 & 0.05 & 0.49 & 0.13 & 0.81 & 0.40 & 0.93 & 0.64 & 0.93 & 0.65 & 0.32 & 0.20 & 0.35 & 0.14 & 0.07 & 0.61 \\
\hline
\end{tabular}

PAAS values (Post-Archean Australian Shale of Taylor and McLennan, 1985) were used to normalize the raw REE data. 


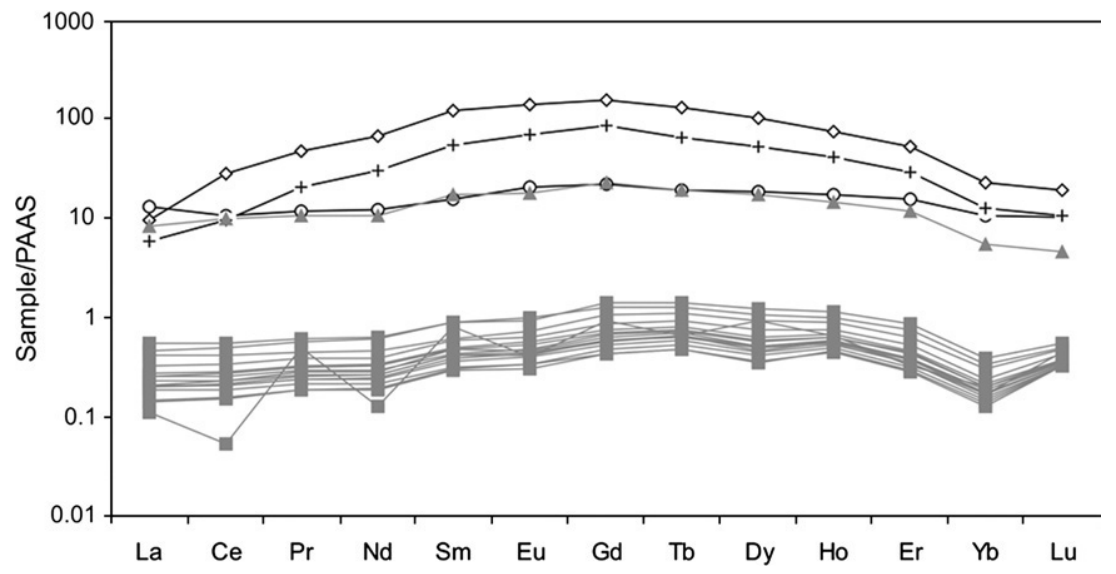

Fig. 3. Rare Earth Element (REE) patterns of Early Danian lepisosteid vertebra ( $n=1$; grey triangles) and ganoine ( $n=16$; grey squares) from Fontllonga-3 and Late Cretaceous vertebrate remains from Laño (white circle), Urria (cross) and Cuezva (white diamond). The samples from Fontllonga-3 display a "hat-shaped" pattern similar to that provided by the Laño samples. Urria and Cuezva samples show a "bell-shaped" pattern with strong middle REE enrichments. Concentrations are normalized to the Post-Archean Australian Shale (PAAS) defined by Taylor and McLennan (1985). Data from Laño, Urria and Cuezva are from Lécuyer et al. (2003b).

of REE-bearing fluids. In contrast, Lécuyer et al. (2003b) suggested that the flat REE profile for the Laño samples indicates the absence of late stage diagenesis and recrystallization. As the Fontllonga-3 samples display a flat REE pattern similar to Laño it can be argued that they also have not experienced any significant late stage diagenesis or recrystallization.

Furthermore, Lécuyer et al. (2003b) argued that REE patterns from Laño are compatible with adsorption mechanisms from sediments deposited in estuarine or littoral environments. Fig. 4 shows the position of a representative lepisosteid vertebra and the mean value of 16 lepisosteid ganoine samples from Fontllonga-3 in the $(\mathrm{La} / \mathrm{Yb})_{\mathrm{N}}$ versus $(\mathrm{La} / \mathrm{Sm})_{\mathrm{N}}$ diagram proposed by Reynard et al. (1999) and used by Lécuyer et al. (2003b). The samples from Fontllonga-3 are situated between an estuarine and a riverine environment, in agreement with other sedimentological studies indicating an upper estuarine environment for Unit 2 of the Tremp Formation (cf. López-Martínez et al., 1998).

\subsection{Stable isotopes}

Results of the stable isotope analyses of the fossils from Fontllonga-3 are presented in Table 2. LópezMartínez et al. (1998) have previously measured $\delta^{18} \mathrm{O}$ and $\delta{ }^{13} \mathrm{C}$ ratios along $\sim 300 \mathrm{~m}$ of the Fontllonga section from different non-skeletal carbonates (limestones, marls, oncoids and palaeosol nodules). According to these authors, isotopic variations across the section record two transgressive episodes, with petrographic studies detecting no major diagenetic processes (LópezMartínez et al., 1998). This is further supported by the low correlation coefficient between $\delta^{13} \mathrm{C}$ and $\delta^{18} \mathrm{O}$ in the $\sim 300 \mathrm{~m}$ of the Fontllonga section $(R=0.11)$, which suggests limited modification of the primary isotopic signal due to diagenetic processes (Jenkyns, 1996; Mitchell et al., 1997). In this study, the Fontllonga-3 isotope results from multiple palaeoproxies also show a low correlation value $(R=0.27)$, suggesting limited diagenetic alteration.

In addition, the carbonate isotopic values corresponding to the Fontllonga-3 site reported by LópezMartínez et al. (1998) are $\delta^{18} \mathrm{O}=-4.95 \%$ and $\delta^{13} \mathrm{C}=$ $-7.39 \%$, which are in agreement with most of the values of the Fontllonga-3 fossils shown in this study (Table 2). Also, Mayr et al. (1999) found similar $\delta^{18} \mathrm{O}$ values $\left(-4.37 \pm 0.30 \%\right.$ ) , but a little heavier $\delta^{13} \mathrm{C}$ values $(-6.56 \pm 0.39 \%$ ), to those of the Fontllonga- 3 fossils, in an oncolite from a level temporarily and spatially close to Fontllonga-3 (Fig. 5.). The lighter content of the $\delta{ }^{13} \mathrm{C}$ isotopic values in the Fontllonga-3 samples could be due to isotopic fractionation of the skeletal material (i.e. vital effect, Urey et al., 1951). The isotopic values from the Fontllonga-3 fossils (Fig. 5) are also in good agreement with the isotopic values of the carbonate nodules from the lower Esplugafreda section $\left(\delta^{18} \mathrm{O}=-4.85 \pm 0.21 \%\right.$; $\delta{ }^{13} \mathrm{C}=-9.85 \pm 0.63 \%$ ) (Schmitz and Pujalte, 2003), although it is somewhat younger (Thanetian) than Fontllonga-3.

Therefore in summary, the isotopic composition of the Fontllonga-3 fossils are compatible with that of the non- 


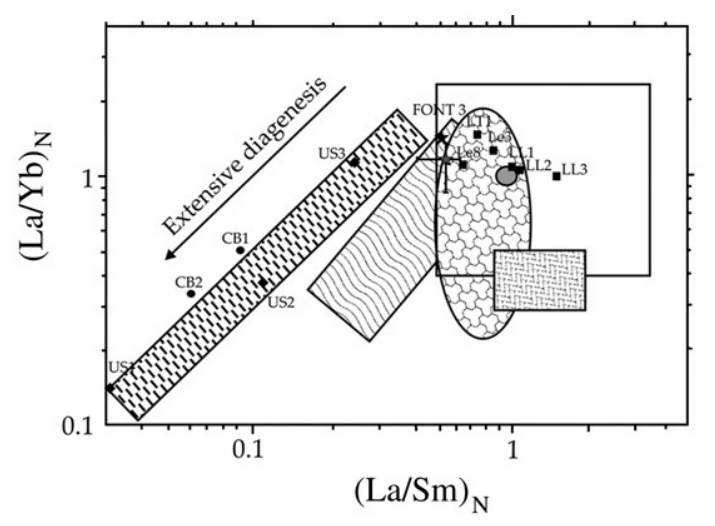

Palaeozoic to Cenozoic conodonts, brachiopods and fish with "bell-shape" REE patterns

$\begin{array}{ll} & \text { Mesozoic to Quaternary fish } \\ & \text { Modern seawater } \\ & \text { Shales } \\ & \text { Lepisosteid vertebra from Fontllonga-3 } \\ & \text { Vertebrate remains from Laño } \\ & \text { Vertebrate remains from Urria } \\ & \text { Vertebrate remains from Cuezva }\end{array}$

Fig. 4. Normalized $\mathrm{La} / \mathrm{Yb}$ ratio versus $\mathrm{La} / \mathrm{Sm}$ ratios of earliest Danian lepisosteid vertebra $(n=1)$ and ganoine $(n=16)$ from Fontllonga-3 and Late Cretaceous vertebrate remains from Laño (LL1, LL2, LL3, Le3, Le8 and LT1) Urria (US1, US2 and US3) and Cuezva (CB1 and CB2). Diagram proposed by Reynard et al. (1999) and modified by Lécuyer et al. (2003b). Lepisosteid vertebra and ganoine from Fontllonga-3 shows an intermediate position between estuarine and river water in agreement with other sedimentological studies that indicate an upper estuarine environment for Unit 2 of the Tremp Formation. The samples from Fontllonga-3 display a low degree of diagenesis.

skeletal sub-contemporaneous carbonates, indicating that they may be recording the surface waters during carbonate formation, or more likely, the groundwater of the burial environment during an early diagenetic stage, as shown by the REE pattern (Lécuyer et al., 2003b).

\subsection{Ba/Ca palaeothermometer}

Table 3 shows the $\mathrm{Ba} / \mathrm{Ca}$ ratios and palaeotemperature values measured on 25 lepisosteid ganoine samples from Fontllonga-3. In the calculation of the palaeotemperatures, the mean $\mathrm{Ba} / \mathrm{Ca}$ ratio of the water from which the ganoine was precipitated was assumed to be 0.001
(Balter and Lécuyer, 2004). The mean temperature value for Fontllonga-3 is $28.0 \pm 6.7{ }^{\circ} \mathrm{C}$ which is compatible with the temperature values suggested by two orders of fishes found at Fontllonga-3 (see point 5.1 of the Discussion).

\section{Discussion}

\subsection{Palaeotemperature and $\delta^{18} \mathrm{O}$ of local water}

Reconstructing palaeotemperatures has become one of the most interesting topics in the study of past palaeoenvironments. Usually, these methods have been applied to marine invertebrate fossils (see Zachos et al., 2001 and references herein). However, palaeotemperature studies using continental and marine vertebrate fossils are experiencing an increase in usage (Koch et al., 1992, 1995; Fricke et al., 1998; Grimes et al., 2003; Pucéat et al., 2003; Lécuyer et al., 2003a; Tütken et al., 2006; Billon-Bruyat et al., 2005).

The $\delta^{18} \mathrm{O}$ values recorded in both vertebrate and invertebrate skeletal remains are controlled by a number of different factors (humidity, ice volume, salinity etc.) among which, the temperature and the $\delta^{18} \mathrm{O}_{\text {water }}$ values are usually considered the most influential. Vital effects may also influence $\delta^{18} \mathrm{O}$ values due to differences in metabolic rates showed by the species considered in every study (Urey et al., 1951). In marine studies, $\delta^{18} \mathrm{O}_{\text {water }}$ is reasonably well constrained between approximately $-1 \%$ (ice-free world) and $0 \%$ (ice caps in the poles) (Lécuyer et al., 2003a). In continental studies though where $\delta^{18} \mathrm{O}_{\text {water }}$ is highly variable, phosphate oxygen isotopic analyses on mammal tooth enamel formed at a stable body temperature $\left(37^{\circ} \mathrm{C}\right)$ can be used to infer it (Grimes et al., 2003; Tütken et al., 2006). In this study, the scarce amount of mammal teeth makes this method of constraining the $\delta^{18} \mathrm{O}$ of local water not viable. Therefore, in this study, an alternative approach was adopted.

First a mean palaeotemperature value of $28.0 \pm 6.7^{\circ} \mathrm{C}$ was estimated using the ganoine of lepisosteid scales and the $\mathrm{Ba} / \mathrm{Ca}$ palaeothermometer proposed by Balter and Lécuyer (2004). This mean palaeotemperature is considered an estimate as it is the first time the $\mathrm{Ba} / \mathrm{Ca}$ palaeothermometer has been applied to non-marine fish remains and also the temperature is highly dependent upon the assumed $\mathrm{Ba} / \mathrm{Ca}$ ratio $(0.001)$ of the water from which the ganoine of lepisosteid scales precipitated. There is not a consensus regarding the $\mathrm{Ba} / \mathrm{Ca}$ ratio in continental environments. On account of this lack of information, the modern day $\mathrm{Ba} / \mathrm{Ca}$ ratio from seawater has been used, even though our lepisosteid scales were 
Table 2

$\delta^{13} \mathrm{C}$ and $\delta^{18} \mathrm{O}$ ratios from the fossils analysed at the Fontllonga-3 site

\begin{tabular}{|c|c|c|c|c|c|}
\hline Signature & Sample & $\delta^{13} \mathrm{C}(\% \mathrm{VPDB})$ & $\begin{array}{l}\text { Mean } \delta^{13} \mathrm{C} \\
\text { value } \pm 1 \mathrm{SD}(\% \mathrm{VPDB})\end{array}$ & $\delta^{18} \mathrm{O}_{\mathrm{CO} 3}(\% \mathrm{VPDB})$ & $\begin{array}{l}\text { Mean } \delta^{18} \mathrm{O}_{\mathrm{CO} 3} \\
\text { value } \pm 1 \mathrm{SD}(\% \text { VPDB })\end{array}$ \\
\hline L-FONT 3-01 & Charophyte gyrogonite & -8.41 & $-8.56 \pm 0.04(n=6)$ & -5.29 & $-5.15 \pm 0.05(n=6)$ \\
\hline L-FONT 3-01-2 & Charophyte gyrogonite & -8.57 & & -5.18 & \\
\hline L-FONT 3-01-3 & Charophyte gyrogonite & -8.58 & & -5.04 & \\
\hline L-FONT 3-01-4 & Charophyte gyrogonite & -8.5 & & -4.95 & \\
\hline L-FONT 3-01-5 & Charophyte gyrogonite & -8.62 & & -5.2 & \\
\hline L-FONT 3-01-6 & Charophyte gyrogonite & -8.68 & & -5.21 & \\
\hline L-FONT 3-02 & Gastropod & -7.91 & $(n=1)$ & -4.17 & $(n=1)$ \\
\hline L-FONT 3-03 & Ostracod (articulated) & -8.38 & $-8.69 \pm 0.10(n=8)$ & -4.69 & $-4.93 \pm 0.21(n=8)$ \\
\hline L-FONT 3-03-1 & Ostracod (articulated) & -8.6 & & -4.73 & \\
\hline L-FONT 3-03-3 & Ostracod (articulated) & -9 & & -5.91 & \\
\hline L-FONT 3-03-4 & Ostracod (articulated) & -8.97 & & -5.23 & \\
\hline L-FONT 3-03-6 & Ostracod (articulated) & -8.97 & & -5.23 & \\
\hline L-FONT 3-03-7 & Ostracod (articulated) & -8.45 & & -4.42 & \\
\hline L-FONT 3-03-8 & Ostracod (articulated) & -8.5 & & -4.33 & \\
\hline L-FONT 3-04 & Ostracod (disarticulated) & -9.51 & & -5.5 & \\
\hline L-FONT 3-05 & Lepisosteid bone & -9.11 & $-9.51 \pm 0.20(n=5)$ & -5.91 & $-5.44 \pm 0.15(n=5)$ \\
\hline L-FONT 3-05-1 & Lepisosteid bone & -10.29 & & -5.3 & \\
\hline L-FONT 3-05-2 & Lepisosteid bone & -9.39 & & -4.97 & \\
\hline L-FONT 3-05-3 & Lepisosteid bone & -9.32 & & -5.44 & \\
\hline L-FONT 3-05-4 & Lepisosteid bone & -9.46 & & -5.58 & \\
\hline L-FONT 3-06 & Pycnodont vomerine tooth & -8.65 & $-8.69 \pm 0.06(n=2)$ & -4.2 & $-5.37 \pm 1.65(n=2)$ \\
\hline L-FONT 3-06-1 & Pycnodont vomerine tooth & -8.74 & & -6.54 & \\
\hline L-FONT 3-07 & Lepisosteid complete scale & -8.75 & $-9.11 \pm 0.52(n=2)$ & -4.45 & $-4.64 \pm 0.28(n=2)$ \\
\hline L-FONT 3-07-1 & Lepisosteid complete scale & -9.48 & & -4.84 & \\
\hline L-FONT 3-08-1 & Lepisosteid ganoine & -9.65 & $(n=1)$ & -5.78 & $(n=1)$ \\
\hline L-FONT 3-09-1 & Pycnodont branchial tooth & -9.09 & $(n=1)$ & -7.04 & $(n=1)$ \\
\hline L-FONT 3-11 & Lepisosteid isopedine & -10.2 & $-9.98 \pm 0.3(n=2)$ & -4.24 & $-4.66 \pm 0.59(n=2)$ \\
\hline L-FONT 3-11-1 & Lepisosteid isopedine & -9.76 & & -5.08 & \\
\hline L-FONT 3-12-1 & Lepisosteid tooth & -9.48 & $(n=1)$ & -6.89 & $(n=1)$ \\
\hline
\end{tabular}

SD refers to standard deviation. $n$ is the number of analysed samples. Values reported in \%o VPDB.

developed in an estuarine environment. Nevertheless the $\mathrm{Ba} / \mathrm{Ca}$ palaeothermometer does appear to generate a mean temperature in agreement with other palaeotemperature estimates for this site. For example, extant relatives of two of the orders of fish recovered from Fontllonga-3 (lepisosteiforms and osteoglossiforms) inhabit tropical and subtropical waters. Osteoglossiforms fish inhabit particularly warm waters, between $24^{\circ}$ and $35^{\circ} \mathrm{C}$ (mean annual temperature $27-30{ }^{\circ} \mathrm{C}$ ) (Johnels, 1954; Lowe McConnell, 1964). Furthermore, the analyses of Late Cretaceous leaf assemblages in the Western Interior (USA) led Wolfe and Upchurch (1987) to propose a mean annual temperature of $27{ }^{\circ} \mathrm{C}$ for a palaeolatitude of $30^{\circ} \mathrm{N}$, which is approximately the same palaeolatitude estimated for Fontllonga-3 (Schmitz and Pujalte, 2003; Fernández-Marrón et al., 2004). Wolfe (1990) also suggested a mean annual temperature (MAT) value of $27.4{ }^{\circ} \mathrm{C}$ just after the $\mathrm{KTb}$ by applying a climate-leaf analysis multivariate program
(CLAMP) to leaf assemblages in the Western Interior (USA). Finally, Frakes et al. (1994) carried out a compilation of temperature data obtained from continental proxies (leaf proportions in plant assemblages, species diversity, oxygen isotope data from fish debris and carbonate concretions) at different palaeolatitudes. For a palaeolatitude of $35^{\circ} \mathrm{N}$, they obtained a MAT value that surpasses $25^{\circ} \mathrm{C}$ in the earliest Paleocene.

Secondly, to calculate $\delta^{18} \mathrm{O}_{\text {water }}$ values the $\mathrm{Ba} / \mathrm{Ca}$ temperature range of $21.3-34.7^{\circ} \mathrm{C}$ was combined with the oxygen isotope results from charophyte gyrogonites, gastropod shells and ostracod valves, using the Hays and Grossman's (1991) freshwater carbonate thermometer. These proxies provide mean $\delta^{18} \mathrm{O}_{\text {water }}$ values of between $-3.75 \%$ and $-0.95 \%$ (VSMOW) respectively.

In contrast to charophytes and invertebrates, the bioapatites from Fontllonga-3 provide a wide range of values for the $\delta^{18} \mathrm{O}_{\mathrm{CO} 3}$ of fish remains, possibly reflecting a vital effect (due to differences in the 


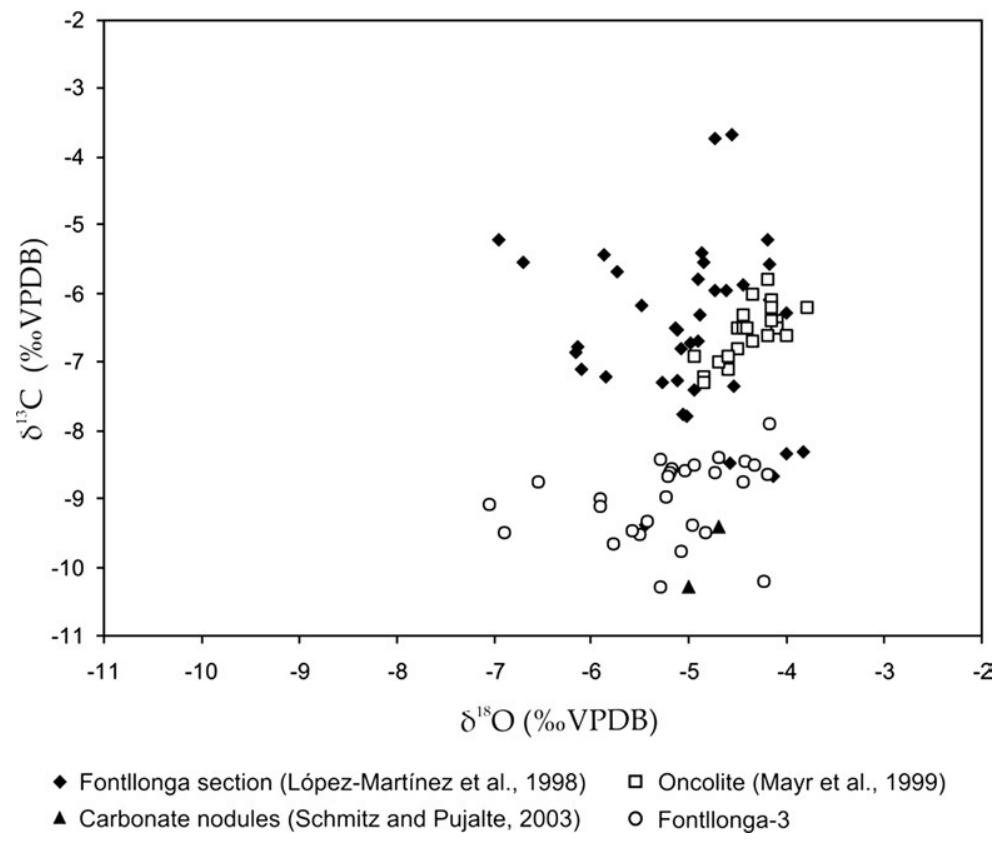

Fig. 5. Comparison of $\delta^{18} \mathrm{O}$ and $\delta^{13} \mathrm{C}$ values from Fontllonga-3 samples, Fontllonga section (López-Martínez et al., 1998), an oncolite (Mayr et al., 1999) and carbonate nodules (Schmitz and Pujalte, 2003). It can be noticed that $\delta^{18} \mathrm{O}$ values from the Fontllonga- 3 fossils agree well with the rest of the values from other studies in the same region. Nevertheless, in the case of $\delta^{13} \mathrm{C}$, Fontllonga- 3 fossils show slightly lighter values compared to those from the Fontllonga section and the oncolite. This fact could be attributed to isotopic fractionation of the skeletal material (vital effect, Urey et al., 1951).

metabolism) or some degree of alteration. $\mathrm{CO}_{3}^{2-}$ from carbonate hydroxyapatite is considered less resistant than $\mathrm{PO}_{4}^{3-}$ to diagenetic alteration (Lécuyer et al., 2003a). Also it is well known that dentine and bone, which have been analyzed here, are less resistant to postmortem oxygen isotope exchange than enamel (Wang and Cerling, 1994; Hoppe et al., 2003; Lee-Thorp and Sponheimer, 2003). However, in this study there is evidence for a low level of diagenetic alteration of the dentine and bone, because intense alteration should bring about a homogenization of the oxygen and carbon isotopic values (Jenkyns, 1996; Mitchell et al., 1997), which is not observed. Furthermore, the isotopic variations do not appear to be correlated with taxa but with skeletal structures and tissues. However, even though the pycnodont branchial tooth has lower than average $\delta^{18} \mathrm{O}(-7.04 \%)$ values, which may be due to diagenetic alteration, the rest of the fish samples (lepisosteid vertebrae, scales, ganoine, isopedine and teeth, and pycnodont vomerine teeth) have $\delta^{18} \mathrm{O}$ of about $-5.52 \%$ (VPDB). This, when combined with a flat REE profile measured on a representative fish vertebra and the lepisosteid ganoine, would suggest only early stage diagenesis has affected these oxygen isotope values.
Kohn and Law (2006) stated that if the $\mathrm{CO}_{3}^{2-}$ component of bone is considered to behave as a normal inorganic carbonate, then this $\mathrm{CO}_{3}^{2-}$ component of bioapatite should follow an oxygen isotope temperature-dependence similar to that of carbonates. Wang and Cerling (1994) assumed that structural carbonate behaves isotopically identical to calcite and that isotopic fractionation between water and dissolved bicarbonate and carbonate of calcite is similar to that between water and dissolved bicarbonate and structural carbonate of apatite. As a consequence of this, it should be possible to apply the carbonate equation (Hays and Grossman, 1991) to the apatite remains in order to compare $\delta{ }^{18} \mathrm{O}_{\text {water }}$ values with those provided by the algae and invertebrate remains from Fontllonga-3. Pycnodont vomerine teeth, lepisosteid bones, complete scales, isopedine and ganoine provide quite similar $\delta^{18} \mathrm{O}_{\text {water }}$ values to those shown by the charophyte gyrogonites, gastropod shells and ostracod valves (i.e. $\delta^{18} \mathrm{O}_{\text {water }}$ of between $-4.01 \%$ and $-1.19 \%$ for a range of temperature of $21.3-34.7{ }^{\circ} \mathrm{C}$, respectively). The $\delta^{18} \mathrm{O}_{\text {water }}$ value provided by the pycnodont branchial tooth, on the other hand give values of $-5.86 \%$ for $21.3{ }^{\circ} \mathrm{C}$ and $-3.43 \%$ for $34.7^{\circ} \mathrm{C}$. 
Table 3

$\mathrm{Ba}$ and $\mathrm{Ca}$ concentrations measured on lepisosteid ganoine and calculated $\mathrm{Ba} / \mathrm{Ca}$ ratios and palaeotemperatures using thermometry equations of Balter and Lécuyer (2004)

\begin{tabular}{|c|c|c|c|c|c|}
\hline Signature & $\begin{array}{l}\mathrm{Ba} \\
\mathrm{mg} / \mathrm{g}\end{array}$ & $\mathrm{Ca} \mu \mathrm{g} / \mathrm{g}$ & $\begin{array}{l}\mathrm{Ba} / \\
\mathrm{Ca}\end{array}$ & $\begin{array}{l}\mathrm{T} \\
\left({ }^{\circ} \mathrm{C}\right)\end{array}$ & $\begin{array}{l}\text { Mean } \\
\mathrm{T}\left({ }^{\circ} \mathrm{C}\right) \pm 1 \mathrm{SD}\end{array}$ \\
\hline FONT 3-07-CG-2 & 112.41 & $393,103.4$ & 0.29 & 21.9 & $28 \pm 6.7$ \\
\hline FONT 3-07-CG-3 & 223.33 & 525,000 & 0.43 & 14.4 & \\
\hline FONT 3-07-CG-4 & 82.95 & $395,348.8$ & 0.21 & 28.0 & \\
\hline FONT 3-07-CG-6 & 74.67 & $398,333.3$ & 0.19 & 30.3 & \\
\hline FONT 3-07-CG-7 & 70.37 & 775,463 & 0.09 & 45.8 & \\
\hline FONT 3-07-CG-8 & 110.05 & $439,153.4$ & 0.25 & 24.5 & \\
\hline FONT 3-07-CG-10 & 103.06 & $407,303.4$ & 0.25 & 24.3 & \\
\hline FONT 3-07-CG-11 & 88.24 & $434,873.9$ & 0.20 & 28.7 & \\
\hline FONT 3-07-CG-13 & 136.61 & $430,803.6$ & 0.32 & 19.9 & \\
\hline FONT 3-07-CG-15 & 73.11 & $397,222.2$ & 0.18 & 30.6 & \\
\hline FONT 3-07-CG-20 & 140.52 & $422,413.8$ & 0.33 & 19.0 & \\
\hline FONT 3-07-CG-21 & 82.80 & 412,000 & 0.20 & 28.9 & \\
\hline FONT 3-07-CG-22 & 65.89 & $405,241.9$ & 0.16 & 33.2 & \\
\hline FONT 3-07-CG-23 & 64.67 & $419,161.7$ & 0.15 & 34.3 & \\
\hline FONT 3-07-CG-24 & 105.84 & $436,131.4$ & 0.24 & 25.1 & \\
\hline FONT 3-07-PG-2 & 72.73 & $439,393.9$ & 0.17 & 32.8 & \\
\hline FONT 3-07-PG-7 & 92.64 & $385,281.4$ & 0.24 & 25.3 & \\
\hline FONT 3-07-PG-8 & 71.55 & $461,340.2$ & 0.16 & 34.2 & \\
\hline FONT 3-07-PG-13 & 66.97 & $374,137.9$ & 0.18 & 31.2 & \\
\hline FONT 3-07-PG-17 & 81.16 & $457,894.7$ & 0.18 & 31.4 & \\
\hline FONT 3-07-PG-18 & 90.52 & $447,916.7$ & 0.20 & 28.7 & \\
\hline FONT 3-07-PG-20 & 70.19 & $441,588.8$ & 0.16 & 33.7 & \\
\hline FONT 3-07-PG-21 & 62.44 & $381,481.5$ & 0.16 & 33.1 & \\
\hline FONT 3-07-PG-22 & 216.67 & $616,666.7$ & 0.35 & 18.0 & \\
\hline FONT 3-07-PG-23 & 120.27 & $422,297.3$ & 0.28 & 22.0 & \\
\hline
\end{tabular}

SD refers to standard deviation.

On one hand, these vertebrate isotopic values could reflect the original composition of the fish skeleton. Kolodny et al. (1996) pointed out that if fossilization, including the replacement of carbonate hydroxyapatite by carbonate fluorapatite, occurs early enough there is a high probability that the recorded signal $\left(\delta^{18} \mathrm{O}_{\text {water }}\right.$ value and therefore the calculated palaeotemperature) may be similar to that recorded in the skeleton of the living organism. On the other hand, these vertebrate derived

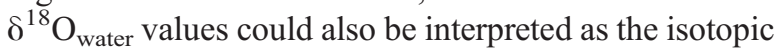
value of the groundwater during burial (Hubert et al., 1996; Lécuyer et al., 2003b). Kolodny et al. (1996) also suggested that if a freshwater fish is buried in locally formed freshwater sediment, both the $\delta^{18} \mathrm{O}_{\text {water }}$ value and the temperature of burial will not differ substantially from the environment in which the fish lived.

The good agreement between the $\delta^{18} \mathrm{O}_{\text {water }}$ values and the sedimentological and the $\mathrm{La} / \mathrm{Yb}$ versus $\mathrm{La} / \mathrm{Sm}$ ratios interpretation (i.e. estuarine, Álvarez-Sierra et al., 1994; López-Martínez et al., 1998; Reynard et al., 1999: Lécuyer et al., 2003b) could suggest that the groundwater during burial was furnished by the estuarine waters as indicated by the REE content in the lepisosteid vertebra and ganoine. This is further supported if we plot $\delta{ }^{18} \mathrm{O}_{\text {water }}$ values provided by all the proxies (algae, invertebrates and vertebrates) from Fontllonga- 3 on a hydrological plot (Fig. 6.). It can be observed that in this figure the Fontllonga-3 fossils plot slightly to the right of values typical of an upper estuary with low salinity values. Mayr et al. (1999) supported this fact as they recorded in the upper part of Unit 2 (where Fontllonga-3 is situated) the replacement of dinoflagellates by Chlorococcaceae, indicating low salinity conditions.

Furthermore, in ideal conditions $\delta^{18} \mathrm{O}$ and $\delta^{13} \mathrm{C}$ in estuarine waters should plot along a salinity gradient which results from a theoretical mixing line between ocean water and freshwater values (Anadón et al., 2002). However, in marginal marine environments with hydrodynamical restrictions, the oxygen isotopic composition of water is also related to evaporation, the relative humidity of the atmosphere, the ionic strength of the fluid, and the isotopic composition of the water vapour in the atmosphere (Swart et al., 1989; Anadón et al., 2002). In this study, the $\delta^{18} \mathrm{O}_{\text {water }}$ results plot to the right of those expected for estuarine conditions suggesting some degree of evaporation.

\subsection{Precipitation}

If it is considered that $\delta^{18} \mathrm{O}_{\text {water }}$ values calculated from Fontllonga-3 reflects the original water or groundwater conditions (upper estuary), it is possible to obtain a preliminary interpretation of the local precipitation rate.

Fontllonga-3 fossils have yielded $\delta^{18} \mathrm{O}_{\text {water values of }}$ between $-4.01 \%$ o $\left(21.3{ }^{\circ} \mathrm{C}\right)$ and $-0.95 \%$ o $\left(34.7{ }^{\circ} \mathrm{C}\right)$. These $\delta^{18} \mathrm{O}_{\text {water }}$ and temperature values, inferred for the fresh-to-oligohalyne estuarine waters of the earliest Danian Fontllonga-3 site, suggest dry climatic conditions, and therefore either a low precipitation rate and/or a high evaporation rate. This is because rain waters in warm climates usually have low $\delta^{18} \mathrm{O}$ ratios because when temperature surpasses a threshold value (established at $20{ }^{\circ} \mathrm{C}$; see Rozanski et al., 1993), the "amount effect" occurs. Above this threshold temperature, further increases in temperature do not impact upon meteoric water $\delta^{18} \mathrm{O}$ values due to this effect (Straight et al., 2004). Therefore, precipitation becomes the most important factor controlling the value of $\delta^{18} \mathrm{O}$ in such a way that a high precipitation rate would tend to lower $\delta^{18} \mathrm{O}_{\text {water }}$ values.

With the aim of obtaining information about the precipitation rate existing in the earliest Danian of the South Central Pyrenees, a study based on present day data 


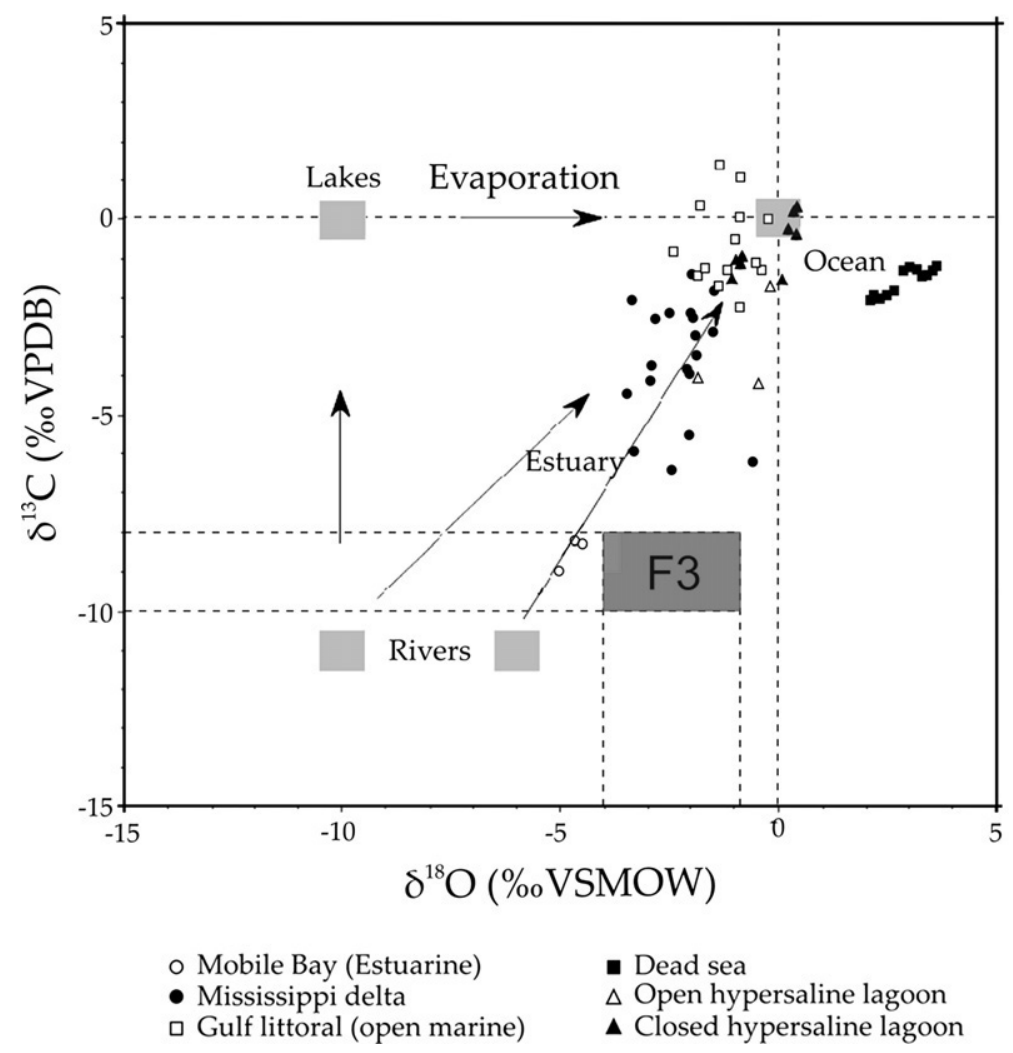

Fig. 6. $\delta^{13} \mathrm{C}$ versus $\delta^{18} \mathrm{O}$ hydrological plot (Soler-Gijón et al. unpublished). The values of $\delta^{18} \mathrm{O}_{\text {water }}$ obtained from the fossils (algae, invertebrates and vertebrates) of Fonllonga-3 (-4.01 to $-0.95 \%$ VSMOW, for a range of temperature of between 21.3 and $34.7^{\circ} \mathrm{C}$, respectively) agree well with estuarine water values. However, it can be noticed that they plot slightly to the right of the values typical for this kind of environment suggesting some degree of evaporation. F3 refers to Fontllonga-3.

concerning the relationship between $\delta^{18} \mathrm{O}$ of the precipitation $\left(\delta^{18} \mathrm{O}_{\mathrm{pt}}\right)$ and the precipitation rate has been developed. Information from tropical and subtropical stations has been obtained from the ISOHIS database (www.isohis.org). Fig. 7 shows this present day relationship. Following Fricke and O’Neil's (1999) example, December, January and February have been taken to represent winter months and June, July and August summer months in the case of the North Hemisphere stations, and vice versa in the case of the South Hemisphere. The values shown in Fig. 7 indicate that $\delta^{18} \mathrm{O}_{\mathrm{pt}}$ values can be considerable lower $(\sim-11.30 \%$ ) than the lowest $\delta^{18} \mathrm{O}_{\text {water }}$ values obtained in Fontllonga-3 $(-4.01 \%)$ indicating a low precipitation rate and/or a high evaporation rate at this site. Furthermore, the number of stations with heavy $\delta{ }^{18} \mathrm{O}_{\mathrm{pt}}$ values (similar to those of Fontllonga-3, $-4.01 \%$ to $-0.95 \%$ ) decreases with increased precipitation rate (Fig. 8). Based upon this modern day relationship it could be argued that the precipitation rate was low at the beginning of the Paleocene in the South Central Pyrenees.
This notion is supported by other studies involving precipitation rates across the KTb. For example, Adatte et al. (2002) carried out a study from CretaceousPaleocene marine deposits in Tunisia, and discovered evidence based upon kaolinite/smectite ratios for a change from humid and warm conditions to seasonal dry conditions in the proximity of the KTb. Stüben et al. (2002) also proposed dry and warm conditions just above the KTb based upon kaolinite/smectite ratios in the Mediterranean region. Similarly, Pucéat et al. (2003) proposed a change in climatic conditions from a humid subtropical climate in the Middle Cretaceous to dry conditions in the Late Cretaceous, based on the study of $\delta^{18} \mathrm{O}_{\mathrm{PO} 4}$ in fish tooth enamel from the western Tethys platform.

Therefore based upon these studies and the results from this study it can be argued that the Fontllonga-3 site experienced a seasonal dry climate where temperature would have been high and the precipitation rate would not have reached significant levels. This agrees with the palaeobotanical evidence of López-Martínez 


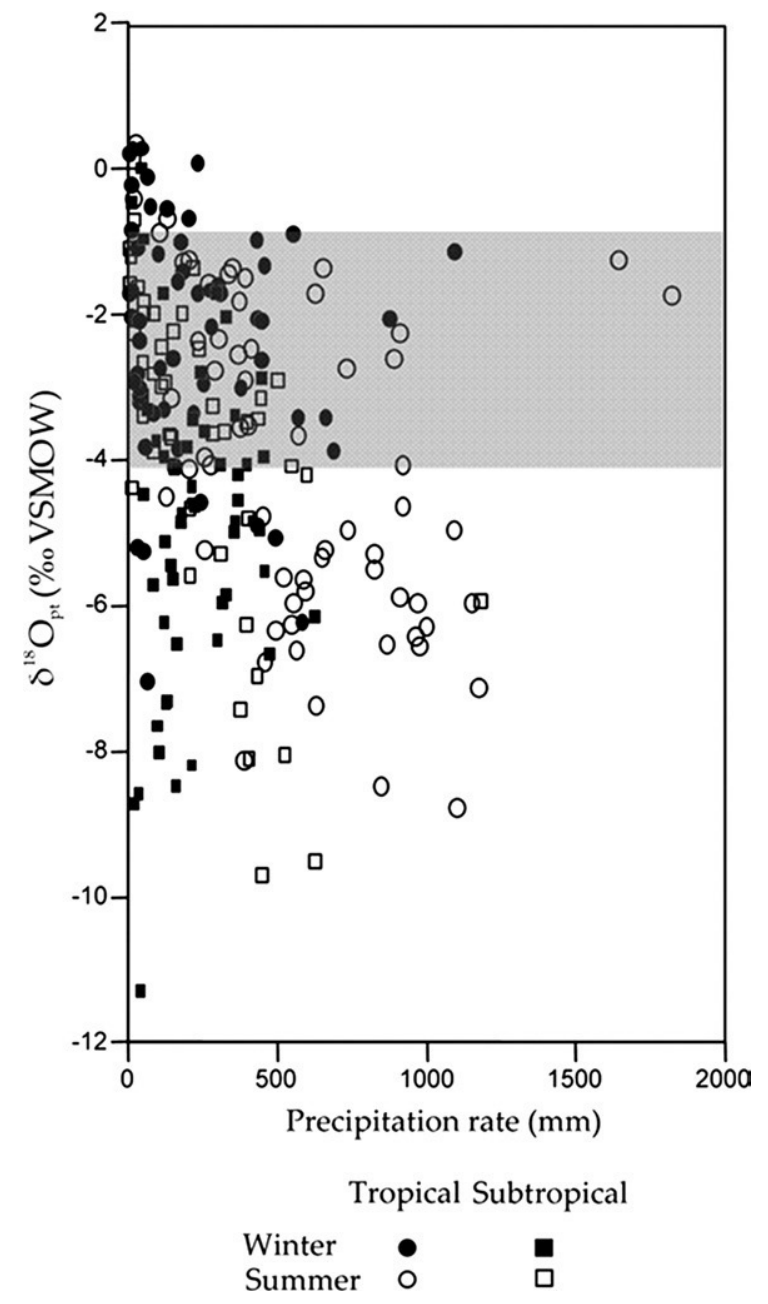

Fig. 7. $\delta^{18} \mathrm{O}$ of the precipitation $\left(\delta^{18} \mathrm{O}_{\mathrm{pt}}\right)(\% \mathrm{VSMOW})$ versus seasonal precipitation rate $(\mathrm{mm})$ from tropical and subtropical stations. The grey area shows the range of $\delta^{18} \mathrm{O}_{\text {water }}$ provided by Fontllonga-3 fossils $\left(-4.01 \%\right.$ o to $-0.95 \%$ v VSMOW). $\delta^{18} \mathrm{O}_{\mathrm{pt}}$ could reach considerable lower values than the lowest $\delta^{18} \mathrm{O}_{\text {water }}$ values obtained from Fontllonga-3 fossils due to the amount effect. Data provided by IAEA (2004). Isotope Hydrology Information System. The ISOHIS Database. http://isohis.iaea.org.

et al. (1999) from another earliest Danian site close to Fontllonga-3 in the Fontllonga section. Microphyll leaves dominate the foliar assemblage, which can indicate either a subtropical seasonally dry climate or a warm-temperate moist climate. However, the abundance of mesotherm taxa, the presence of evergreen angiosperms (Magnoliaceae and Lauraceae) and the presence of entire-margined leaves would indicate a subtropical climate. Therefore, López-Martínez et al. (1999) conclude that during the earliest Paleocene a subtropical seasonally dry climate may have occurred in the South Central Pyrenees.

\section{Conclusions}

In this study, a fossil assemblage from the earliest Danian Fontllonga-3 site (South Central Pyrenees, Lleida, Spain) has been isotopically and geochemically analysed for palaeoclimatic information. By applying the $\mathrm{Ba} / \mathrm{Ca}$ palaeothermometer on lepisosteid ganoine, a mean temperature value of $28.0 \pm 6.7{ }^{\circ} \mathrm{C}$ has been obtained. This temperature range agrees well with that obtained from fish remains when considering the tolerance levels of their nearest living relatives and it is also confirmed by previous palaeoclimate studies from around the Cretaceous-Tertiary boundary. Using a temperature range of $21.3{ }^{\circ} \mathrm{C}-34.7{ }^{\circ} \mathrm{C}$ and the isotopic ratios measured on fossil charophyte, invertebrates and vertebrates, it is possible to calculate the $\delta^{18} \mathrm{O}_{\text {water }}$ value of between $-4.01 \%$ and $-0.95 \%$ (VSMOW). These inferred $\delta{ }^{18} \mathrm{O}_{\text {water }}$ values, in conjunction with $(\mathrm{La} / \mathrm{Yb})_{\mathrm{N}}$ versus $(\mathrm{La} / \mathrm{Sm})_{\mathrm{N}}$ plots, correspond to the range of values expected for an estuary, which agrees well with the previous sedimentary interpretation of the Fontllonga-3 deposits. The $\delta^{18} \mathrm{O}$ values recorded on vertebrates are, in general, in good agreement with those recorded on the charophyte and invertebrates. This, in conjunction with the REE profiles, suggests only minimal early stage groundwater diagenesis occurred during the burial of the vertebrate fossil remains.

Finally, combined charophyte, invertebrate and vertebrate $\delta^{18} \mathrm{O}_{\text {water }}$ results allow an estimation of the precipitation rate to be determined. Based upon a comparison with modern day meteorical conditions it can be inferred that the Fontllonga-3 site experienced a warm, seasonally dry climate during the early Paleocene. This notion is fully supported by other palaeobotanical and mineralogical studies.

\section{Acknowledgments}

This work was supported by the project BTE 20021430 "Cambios paleoambientales y paleoclimáticos en el tránsito Cretácico-Terciario en la Unidad Surpirenaica Central" of the Plan Nacional I+ D of the Spanish Ministerio de Educación y Ciencia and by a FPU doctoral grant of the Ministerio de Educación y Ciencia to L. Domingo. The work conducted by S. Grimes was supported by a Natural Environmental Research Council (NERC) New Investigators grant (NE/C507237/1). Authors are grateful to Dr. C. Recio Hernández and A. Martín Monge (Servicio General de Análisis de Isótopos Estables, Salamanca University, Spain) for the help with the isotopic analyses. We thank Dr. Finn Surlyk, 


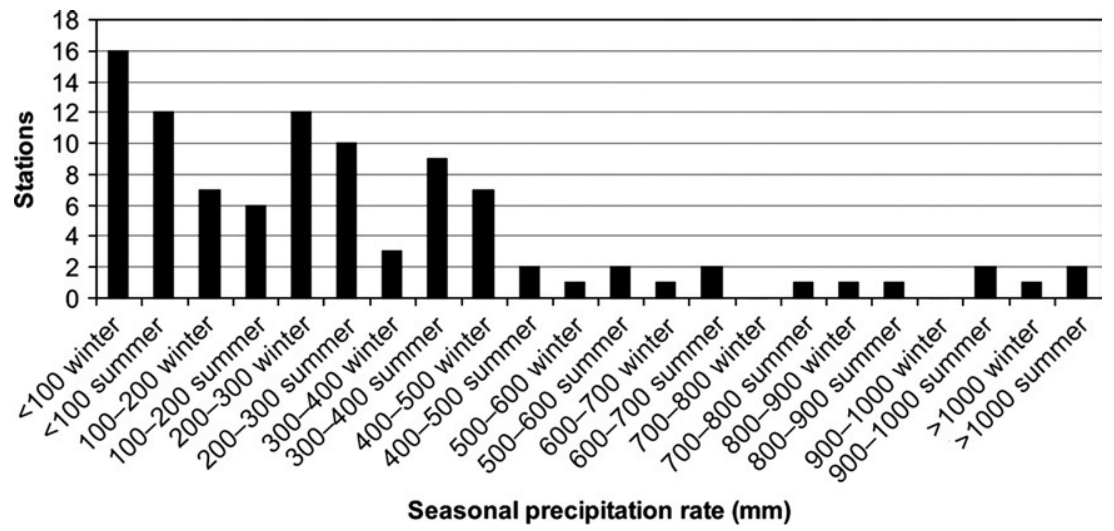

Fig. 8. Tropical and subtropical stations showing similar $\delta^{18} \mathrm{O}_{\mathrm{pt}}$ values to those obtained in Fontllonga-3 (-4.01\%o to $-0.95 \%$, VSMOW) versus seasonal precipitation rate. A decrease in the number of stations as precipitation rate rises can be observed. Palaeobotanical data in the Fontllonga section provided by López-Martínez et al. (1999) also points to a dry climate in the area. Data provided by IAEA (2004). Isotope Hydrology Information System. The ISOHIS Database. http://isohis.iaea.org.

Dr. M. I. Benito and two anonymous reviewers for their valuable comments that improved the manuscript.

\section{References}

Adatte, T., Keller, G., Stinnesbeck, W., 2002. Late Cretaceous to early Paleocene climate and sea-level fluctuations: the Tunisian record. Palaeogeography Palaeoclimatology Palaeoecolology 178, 165-196.

Álvarez-Sierra, Ma. A., Arribas, Ma. E., Ardévol, L., Civis, J., Daams, R., Krauss, S., López-Martínez, N., de la Peña, A., Soler, R., VianeyLiaud, M., Lacasa, A., Marandat, B., Peláez-Campomanes, P., Sevilla, P., Sigé, B., 1994. El límite Cretácico-Terciario en la sección de Fontllonga (Cuenca de Ager, provincia de Lérida). II Congreso G. E. T. Jaca, Comunicaciones, pp. 23-26.

Anadón, P., Gliozzi, E., Manzini, I., 2002. Paleoenvironmental reconstruction of marginal marine environments from combined paleoecologicaland geochemical analyses on ostracods. The Ostracoda: applications in Quaternary research. Geophysical Monograph $131,227-247$.

Ayliffe, L.K., Chivas, A.R., Leakey, M.G., 1994. The retention of primary oxygen isotope compositions of fossil elephant skeletal phosphate. Geochimica et Cosmochimica Acta 58, 5291-5298.

Balter, V., Lécuyer, C., 2004. Determination of Sr and Ba partition coefficients between apatite and water from $5{ }^{\circ} \mathrm{C}$ to $60{ }^{\circ} \mathrm{C}$ : a potential new thermometer for aquatic paleoenvironments. Geochimica et Cosmochimica Acta 68, 423-432.

Billon-Bruyat, J.-P., Lécuyer, C., Martineau, F., Mazin, J.-M., 2005. Oxygen isotope compositions of Late Jurassic vertebrates remains from lithographic limestones of western Europe: implications for the ecology of fish, turtles, and crocodilians. Palaeogeography, Palaeoclimatology, Palaeoecology 216, 359-375.

Bocherens, H., Koch, P.L., Mariotti, A., Geraads, D., Jaeger, J.-J., 1996. Isotopic biogeochemistry $\left({ }^{13} \mathrm{C},{ }^{18} \mathrm{O}\right)$ of mammalian enamel from African Pleistocene hominid sites. Palaios 11, 306-318.

Bryant, J.D., Froelich, P.N., Showers, W.J., Genna, B.J., 1996. A tale of two quarries: biologic and taphonomic signatures in the oxygen isotope composition of tooth enamel phosphate from modern and Miocene equids. Palaios 11, 397-408.
Corfield, R.M., 1994. Palaeocene oceans and climate: an isotopic perspective. Earth-Science Reviews 37, 225-252.

Feist, M., Colombo, F., 1983. La limite Crétacé-Tertiaire dans le nord-est de l'Espagne, du point de vue des charophytes. Géologie Méditerranéenne 10, 303-326.

Fernández-Marrón, M.T., López-Martínez, N., Fonollá-Ocete, J.F., Valle-Hernández, M.F., 2004. The palynological record across the Cretaceous-Tertiary boundary in differing palaeogeographical settings from the southern Pyrenees, Spain. In: Beaudoin, A.B., Head, M.J. (Eds.), The Palynology and Micropaleontology of Boundaries. Geological Society, London, Special Publications, vol. 230, pp. 243-255.

Frakes, L.A., Probst, J.-L., Ludwig, W., 1994. Latitudinal distribution of paleotemperature on land and sea from early Cretaceous to middle Miocene. Comptes rendus de l'Académie des sciences. Paris 318, 1209-1218.

Fricke, H.C., Clyde, W.C., O’Neil, J.R., Gingerich, P.D., 1998. Evidence for rapid climate change in North America during the latest Paleocene thermal maximum: oxygen isotope compositions of biogenic from the Bighorn Basin (Wyoming). Earth and Planetary Science Letters 160, 193-208.

Fricke, H.C., O'Neil, J.R., 1999. The correlation between ${ }^{18} \mathrm{O} /{ }^{16} \mathrm{O}$ ratios of meteoric water and surface temperature: its use in investigating terrestrial climate change over geologic time. Earth and Planetary Science Letters 170, 181-196.

Galbrun, B., Feist, M., Colombo, F., Rocchia, R., Tambareau, Y., 1993. Magnetostratigraphy and biostratigraphy of Cretaceous-Tertiary continental deposits, Ager basin, province of Lerida, Spain. Palaeogeography, Palaeoclimatology, Palaeoecology 102, 41-52.

Grimes, S.T., Mattey, D.P., Hooker, J.J., Collinson, M.E., 2003. Paleogene paleoclimate reconstruction using oxygen isotopes from land and freshwater organisms: the use of multiple paleoproxies. Geochimica et Cosmochimica Acta 67, 4033-4047.

Grimes, S.T., Hooker, J.J., Collinson, M.E., Mattey, D.P., 2005. Summer temperatures of late Eocene to early Oligocene freshwaters. Geology 33, 189-192.

Hays, P.D., Grossman, E.L., 1991. Oxygen isotopes in meteoric calcite cements as indicators of continental paleoclimate. Geology 19, $441-444$. 
Higgins, P., MacFadden, B.J., 2004. Amount effect" recorded in oxygen isotopes of Late Glacial horse (Equus) and bison (Bison) teeth from the Sonoran and Chihuahuan Deserts, southwestern United States. Palaeogeography, Palaeoclimatology, Palaeoecology 206, 337-353.

Hoppe, K.A., Koch, P.L., Furutani, T.T., 2003. Assessing the preservation of biogenic strontium in fossil bones and tooth enamel. International Journal of Osteoarchaeology 13, 20-28.

Huber, B.T., Hodell, D.A., Hamilton, C.P., 1995. Middle-Late Cretaceous climate of the southern high latitudes: stable isotopic evidence for minimal equator-to-pole thermal gradients. Geological Society of American Bulletin 107, 1164-1191.

Hubert, J.F., Panish, P.T., Chure, D.J., Prostak, K.S., 1996. Chemistry, microstructure, petrology, and diagenetic model of Jurassic dinosaur bones, Dinosaur National Monument, Utah. Journal of Sedimentary Research 66, 531-547.

Hsü, K.J., McKenzie, J.A., 1985. A “Strangelove” Ocean in the earliest Tertiary. American Geophysical Union, Geophysical Monographs 32, 487-492.

La limite Crétacé-Tertiaire dans le basin de L'Arc (Sud-est, France). In: Jaeger, J.J., Westphal, W. (Eds.), Cahiers réserve géologique de Haute Provence, Digne 1.

Jenkyns, H.C., 1996. Relative sea-level change and carbon isotopes: data from the Upper Jurassic (Oxfordian) of central and Southern Europe. Terra Research 8, 75-85.

Johnels, A.G., 1954. Notes on fishes from the Gambia River. Arkiv för Zoologi, ser. 2, 6 (17), 327-411.

Kaiho, K., Kajiwara, Y., Tazaki, K., Ueshima, M., Takeda, N., Kawahata, H., Arinobu, T., Ishiwatari, R., Hirai, A., Lamolda, M.A., 1999. Oceanic primary productivity and dissolved oxygen levels at the Cretaceous/Tertiary boundary: their decrease, subsequent warming, and recovery. Paleoceanography 14, 511-524.

Kedves, M., 1982. Palynology of the Thanetian layers of Menat. Palaentographica B, 182, 87-150.

Kennett, J.P., Stott, L.D., 1990. Abrupt deep-sea warming, paleoceanographic changes and benthic extinctions at the end of the Paleocene. Nature 353, 225-229.

Koch, P.L., Zachos, J.C., Gingerich, P.D., 1992. Coupled isotopic change in marine and continental carbon reservoirs near the Paleocene/Eocene boundary. Nature 358, 319-322.

Koch, P.L., Zachos, J.C., Dettman, D.L., 1995. Stable isotope stratigraphy and paleoclimatology of the Paleogene Bighorn Basin (Wyoming, USA). Palaeogeography, Palaeoclimatology, Palaeoecology 115, 61-89.

Kohn, M.J., Law, J.M., 2006. Stable isotope chemistry of fossil bone as a new paleoclimate indicator. Geochimica et Cosmochimica Acta 70, 931-946.

Kolodny, Y., Luz, B., Sander, M., Clemens, W.A., 1996. Dinosaur bones: fossils or pseudomorphs? The pitfalls of physiology reconstruction from apatitic fossils. Palaeogeography, Palaeoclimatology, Palaeoecology 126, 161-171.

Lécuyer, C., Picard, S., Garcia, J.-P., Sheppard, S.M.F., Grandjean, P., Dromart, G., 2003a. Thermal evolution of Tethyan surface waters during the Middle-Late Jurassic: evidence from $\delta^{18} \mathrm{O}$ values of marine fish teeth. Paleoceanography 18, 21(1)-21(16).

Lécuyer, C., Bogey, C., Garcia, J.-P., Grandjean, P., Barrat, J.-A., Floquet, M., Bardet, N., Pereda-Superbiola, X., 2003b. Stable isotope composition and rare earth element content of vertebrate remains from the Late Cretaceous of northern Spain (Laño): did the environmental record survive? Palaeogeography, Palaeoclimatology, Palaeoecology 193, 457-471.

Lee-Thorp, J., Sponheimer, M., 2003. Three case studies used to reassess the reliability of fossil bone and enamel isotope signals for paleodietary studies. Journal of Anthropological Archaeology 22, 208-216.

Lerbekmo, J.F., St Louis, R.M., 1986. The terminal Cretaceous iridium anomaly in the Red Deer Valley, Alberta, Canada. Canadian Journal of Earth Sciences 23, 120-124.

López-Martínez, N., Ardévol, L., Arribas, Ma. E., Civis, J., GonzálezDelgado, A., 1996. Transición Cretácico/Terciario en depósitos continentales de la cuenca de Tremp-Graus: datos preliminares de isótopos estables de C y O. Geogaceta 20, 62-65.

López-Martínez, N., Ardévol, L., Arribas, Ma. E., Civis, J., GonzálezDelgado, A., 1998. The geological record in non-marine environments around the $\mathrm{K} / \mathrm{T}$ boundary (Tremp Formation, Spain). Bulletin de la Société Géologique de France. 169, 11-20.

López-Martínez, N., Fernández-Marrón, Ma. T., Valle, Ma. F., 1999 The succession of vertebrates and plants across the CretaceousTertiary boundary in the Tremp Formation, Ager Valley (SouthCentral Pyrenees, Spain). Geobios 32, 617-627.

Lowe McConnell, R.H., 1964. The fishes of the Rupununi savanna district of British Guiana, South America. Part 1. Ecological grouping of fish species and effects of the seasonal cycle on the fish. Journal of the Linnean Society (Zoology) 45, 103-144.

MacFadden, B.J., Hochstein, J.L., Quitmyer, I., Jones, D.S., 2004. Incremental growth and diagenesis of skeletal parts of the lamnoid shark Otodus obliquus from the early Eocene (Ypresian) of Morocco. Palaeogeography, Palaeoclimatology, Palaeoecology 206, 179-192.

Margolis, S.V., Mount, J.F., Doehne, E., Showers, W., Ward, P., 1987. The Cretaceous/Tertiary boundary carbon and oxygen isotope stratigraphy, diagenesis and paleoceanography at Zumaya, Spain. Paleoceanography 2, 361-377.

Mayr, C., Thümmler, B., Windmaier, G., Altenbach, A.V., Köhler, H., Tiedemann, R., 1999. New data about the Maastrichtian/Danian transition in the southern Pyrenees (Ager Basin, Catalonia, Spain). Revista española de Micropaleontología 31, 357-368.

Mey, P., Nagtegaal, P.J.C., Roberti, K.J., Hartevelt, J., 1968. Lithostratigraphic subdivision of post-hercynian deposits in the south-central Pyrenees. Spain. Leidse Geologische Mededelingen 41, 221-228.

Mitchell, S.F., Ball, J.D., Crowley, S.F., Marshall, J.D., Paul, C.R.C., Veltkamp, C.J., Samir, A., 1997. Isotope data from Cretaceous chalks and foraminifera: environmental or diagenetic signals? Geology 25, 691-694.

Nagtegaal, P.J.C., Van Vliet, A., Brouwer, J., 1983. Syntectonic coastal off lap and concurrent turbidite deposition: the Upper Cretaceous Aren Sandstone in the South-Central Pyrenees, Spain. Sedimentary Geology 34, 185-218.

Norris, R.D., Wilson, P.A., 1998. Low-latitude sea-surface temperatures for the mid-Cretaceous and the evolution of plantik foraminifera. Geology 26, 823-826.

Peláez-Campomanes, P., López-Martínez, N., Álvarez Sierra, M.A., Daams, R., 2000. The earliest mammal of the European Paleocene: the multituberculate Hainina. Journal of Paleontology 74, 701-711.

Perch-Nielsen, K., McKenzie, J., He, Q., 1982. Biostratigraphy and isotope stratigraphy and the catastrophic extinction of calcareous nannoplankton at the Cretaceous/Tertiary boundary. Geological Society of America. Special Paper 190, 353-371.

Pucéat, E., Lécuyer, C., Sheppard, S.M.F., Dromart, G., Reboulet, S., Grandjean, P., 2003. Thermal evolution of Cretaceous Tethyan marine waters inferred from oxygen isotope composition of fish tooth enamels. Paleoceanography 18, 7-1-7-12.

Reynard, B., Lécuyer, C., Grandjean, P., 1999. Crystal-chemical controls on rare earth element concentrations in fossil biogenic 
apatites and implications for paleoenvironmental reconstructions. Chemical Geology 155, 233-241.

Rozanski, K., Araguas-Araguas, L., Gonfiantini, R., 1993. Isotopic patterns in modern global rainfall. Geophysical Monograph 78, 1-36.

Schmitz, B., Pujalte, V., 2003. Sea-level, humidity and land-erosion records across the initial Eocene thermal maximum from a continental-marine transect in northern Spain. Geology 31, 689-692.

Shackleton, N.J., 1986. Paleogene stable isotope events. Palaeogeography, Palaeoclimatology, Palaeoecology 57, 91-102.

Shackleton, N.J., Opdike, N.D., 1973. Oxygen isotope and paleomagnetic stratigraphy of Equatorial Pacific core V28-238: oxygen isotope temperatures and ice volumes on a $10^{5}$ year and $10^{6}$ year scale. Quaternary Research 3, 39-55.

Smit, J., 1990. Meteorite impact, extinctions and the CretaceousTertiary boundary. Geologie en Mijnbouw 69, 187-204.

Soler-Gijón, R., de la Peña, A., 1995. Fishes from the CretaceousTertiary boundary interval of the Ager basin, Lerida province (Spain). Terra Nostra 65, 73-74.

Soler-Gijón, R., López-Martínez, N., 2005. Late Cretaceous-early Paleocene osteichthyans from the Fontllonga section (SouthCentral Pyrenees, Spain): new record and implications. In: Poyato-Ariza, F.J. (Ed.), Fourth International Meeting on Mesozoic Fishes-Systematics, Homology, and Nomenclature. Madrid. Servicio de Publicaciones de la Universidad Autónoma de Madrid, UAM Ediciones, pp. 229-233.

Straight, W.H., Barrick, R.E., Eberth, D.A., 2004. Reflections of surface water, seasonality and climate in stable oxygen isotopes from tyrannosaurid tooth enamel. Palaeogeography, Palaeoclimatology, Palaeoecology 206, 239-256.

Stüben, D., Kramar, U., Berner, Z., Stinnesbeck, W., Keller, G., Adatte, T., 2002. Trace elements, stable isotopes, and clay mineralogy of the Elles II K-T boundary section in Tunisia: indications for sea level fluctuations and primary productivity. Palaeogeography, Palaeoclimatology, Palaeoecology 178, 321-345.

Swart, P.K., Sternberg, L.D.S.L., Steinen, R., Harrison, S.A., 1989. Controls on the oxygen and hydrogen isotopic composition of the waters of Florida Bay, U.S.A. Chemical Geology 79, 113-123.
Taylor, S.R., McLennan, S.M., 1985. The Continental Crust: Its Composition and Evolution. Blackwell, Oxford.

Tütken, T., Pfretzschner, H.-U., Vennemann, T.W., Sun, G., Wang, Y.D., 2004. Paleobiology and skeletochronology of Jurassic dinosaurs: implications from the histology and oxygen isotope compositions of bones. Palaeogeography, Palaeoclimatology, Palaeoecology 206, 217-238.

Tütken, T., Vennemann, T.W., Janz, H., Heizmann, E.P.J., 2006. Palaeoenvironment and palaeoclimate of the Middle Miocene lake in the Steinheim basin, SW Germany: a reconstruction from C, O, and $\mathrm{Sr}$ isotopes of fossil remains. Palaeogeography, Palaeoclimatology, Palaeoecology 241, 457-491.

Urey, H.C., Lowenstam, H.A., Epstein, S., McKinney, C.R., 1951. Measurement of paleotemperatures and temperatures of the Upper Cretaceous of England, Denmark and the southeastern United States. Bulletin of the Geological Society of America 62, 399-416.

Wang, Y., Cerling, T.E., 1994. A model of fossil tooth and bone diagenesis: implications for paleodiet reconstruction from stable isotopes. Palaeogeography, Palaeoclimatology, Palaeoecology 107, 281-289.

Wolfe, J.A., 1990. Palaeobotanical evidence for a marked temperature increase following the Cretaceous/Tertiary boundary. Nature 343, $153-156$.

Wolfe, J.A., Upchurch Jr., G.R., 1987. North American nonmarine climates and vegetation during the Late Cretaceous. Palaeogeography, Palaeoclimatology, Palaeoecology 61, 33-77.

Zachos, J., Pagani, M., Sloan, L., Thomas, E., Billups, K., 2001. Trends, rhythms, and aberrations in global climate $65 \mathrm{Ma}$ to present. Science 292, 686-693.

Zhao, Z.K., Li, H.M., Zhao, Z., Yan, Z., 1991. Extinction of the dinosaurs across the Cretaceous-Tertiary boundary in Nanxiong basin, Guandong province. Vertebrate PalAsiatica 29, 2. 